\title{
Evaluating Environmental Threats to the Trophic Ecology of Arctic Marine Mammals
}

\author{
Alexander J Werth* \\ Department of Biology, Hampden-Sydney College, Hampden-Sydney, USA
}

\begin{abstract}
Marine mammals of the Arctic, including several species of endemic seals, toothed and baleen whales, and the polar bear, face numerous dangers that also threaten the environment of habitats all over Earth. However, the unique nature of the Arctic Ocean's geography, similar to but in key ways distinct from the Antarctic polar region, place Arctic wildlife, and particularly marine mammals as apex predators at the "top" of food webs, at special risk. Further, the climate of the Arctic is rapidly changing (at an estimated pace of twice the warming of other regions), which places Arctic wildlife at even greater risk. Finally, the unique biology of Arctic mammals, with long lifespans, low growth and reproductive rates, heavy reliance on blubber and importance of thermoregulation in physiology and body form, and other factors due to the extreme seasonality of the boreal polar region, all combine to make Arctic marine mammals highly vulnerable to environmental threats. These threats are only now becoming widely known and demand greater investigation by scientists and attention from conservation groups.
\end{abstract}

Keywords

Ecology, Conservation, Arctic, Polar, Marine, Cetacea, Pinipedia, Feeding

\section{Introduction}

No part of the world remains untouched by environmental dangers, but few places face as much risk as the Arctic polar region. From varied forms of pollution to oil and gas development, overfishing and bycatch, vessel traffic and ship strikes, and of course the far-reaching effects of climate change (estimated at twice the rate of warming of other areas) [1-9], Earth's northern polar region is among the most threatened regions of the planet.

The northern and southern polar regions naturally have many similarities, but there are also crucial differences between the Arctic and Antarctic [10] in geography/geology, biology, and human impact (many of which are summarized in Table 1). These differences - some widely known, some little appreciated [10] - have profound implications for the well-documented current and future environmental dangers threatening polar wildlife, and in virtually all cases the substantial Arctic vs. Antarctic differences lead to much greater risk for Arctic wildlife [11].

Relative to the world's other oceans, the Arctic Ocean is smaller (just over $14 \times 10^{6} \mathrm{~km}^{2}$ ) and shallower (mean depth $1205 \mathrm{~m}$ ), putting it at further risk of environmental damage [11-14]. As the least-explored ocean, there is still much we do not yet know about Arctic oceanography, climatology, geology, and marine biology, and of the environmental threats it faces from human impact. The seven major basins adjoining the Arctic Ocean margins are the
Barents Sea $\left(1.4 \times 10^{6} \mathrm{~km}^{2}\right)$ north of Europe, Kara Sea (3.4 $\times 10^{5} \mathrm{~km}^{2}$ ) north of central Eurasia between Novaya Zemlya and Severnaya Zemlya, Laptev Sea $\left(2.8 \times 10^{5} \mathrm{~km}^{2}\right)$ north of Siberia, Chukchi Sea $\left(2.2 \times 10^{5} \mathrm{~km}^{2}\right)$ north of the Bering Sea, Beaufort Sea $\left(1.8 \times 10^{5} \mathrm{~km}^{2}\right)$ north of Alaska and western Canada, Lincoln Sea $\left(6.4 \times 10^{4} \mathrm{~km}^{2}\right)$ north of Baffin Bay, between Ellesmere Island and Greenland, and Wandel Sea $\left(2.2 \times 10^{4} \mathrm{~km}^{2}\right)$ north of the Greenland Sea, between Greenland and Svalbard. There are other seas, such as the Norwegian and East Siberian, that also make up part of the Arctic Ocean at its edges.

Another way to view and subdivide the Arctic Ocean involves eight major regions: the deep, central Arctic Basin, the Arctic Archipelago (a chain of over 36,500 large and small islands north of continental Canada), the Hudson complex stretching from Hudson Bay to the Arctic Archipelago, the Davis-Baffin complex between Canada and Greenland, the Atlantic Arctic between Greenland and Scandinavia, the Ka-

*Corresponding author: Alexander J Werth, Department of Biology, Hampden-Sydney College, Hampden-Sydney, Virginia 23943, USA

Accepted: September 28, 2019

Published online: September 30, 2019

Citation: Werth AJ (2019) Evaluating Environmental Threats to the Trophic Ecology of Arctic Marine Mammals. J Mar Biol Aquaculture Res 2(1):17-24 
Citation: Werth AJ (2019) Evaluating Environmental Threats to the Trophic Ecology of Arctic Marine Mammals. J Mar Biol Aquaculture Res 2(1):17-24

Table 1: Trophic ecology of the Arctic and Antarctic regions differs widely due to multiple geographic, climatological, biological, and anthropogenic factors.

\begin{tabular}{|l|l|}
\hline Difference & Result \\
\hline
\end{tabular}

\section{Geographic/geological factors}

- Arctic is mostly ocean; Antarctica is solid continent

- Shallow Arctic Ocean has many ridges and seamounts and is largely continental shelf

- Arctic has rim with many active volcanoes; Antarctica has many mountains but only two active volcanoes

- Half of Arctic is continental shelf

- Thousands of islands in Arctic

- Antarctic is much higher

- Stronger sustained winds in Antarctica

- Arctic thought to hold half of world's petroleum deposits; Antarctic rich in minerals

- Arctic has many rivers that feed into it

- Much outflow from and inflow into Arctic from currents and rivers; little in Antarctic

- Arctic region is warmer and thus more susceptible to climate change

- Much greater opportunity for upwelling and trophic exchange in Arctic

- Arctic is warmer, more geologically active, and has more nutrient influx

- Arctic Ocean is shallower and warmer

- Arctic has much more shoreline area

- Antarctic is colder

- Antarctic is colder

- Extensive Arctic energy exploration and extraction; potential for mining of Arctic Ocean bottom but on land in Antarctica

- Arctic receives influx of nutrient-rich organic and inorganic sediments

- Antarctica has single main circumpolar current (surrounding single land mass)

- Deep ocean conveyor carries cold, dense, saline water around Antarctica, but overturns (carrying surface water deeper) at margins of Arctic

- Arctic has more complex system with many currents and gyres, including exchange of warm \& cold waters with Atlantic and Pacific Oceans

- Thinner ice of Arctic (with no continent) leads to leads (channels) and polynyas

- Great exchange of nutrients and other materials in Arctic, leading to complex and varied ecology

- Antarctic has fewer opportunities for heat exchange and is thus colder

- Arctic overturn leads to heat exchange and exchange of organic and inorganic nutrients

- Arctic is oceanographically and climatologically more complex which potentially leads to more complex marine biology

- More open water and more complex ice surface for marine life in Arctic

- Different kinds of ice: Antarctic has freshwater ice \& snow, Arctic has mostly frozen salty seawater ice with some freshwater snow or multi-year ice on top

- Possibly more physically and biologically complex ice surface for marine life in Arctic

- Arctic icebergs smaller, shorter; massive Antarctic bergs are vast shelves or high and deep

- Arctic is warming faster than Antarctic

- Much greater annual fluctuation of Arctic sea ice, plus increasing overall loss

Lots opportunities for Antarctic sea ice algae, but Antarctic ice less prone to melting

- Thinner ice, more nutrient exchange, and more risk to Arctic wildlife

- Short-term annual changes to Arctic ice make ecology more complex; long-term changes put Arctic wildlife at great risk

\section{Major biological factors}

- Arctic has flora with vast tundra, Antarctica has no vegetation except few lichens

- Arctic supports terrestrial herbivores (caribou, musk ox, hares, lemmings) which are involved in biogeochemical cycles and release waste which flows into Arctic

- Arctic climate and herbivores support large terrestrial/ marine predators (polar bear, wolf, fox)

- Marine mammals of Antarctic do not face threat of predators from land

- Both Arctic and Antarctic have marine predators (killer whales, leopard seals)

- Both Arctic and Antarctic have endemic seals, but whales of Arctic are also endemic

- Marine mammals of Antarctic face predation only at sea

- Arctic whales remain within Arctic; Antarctic whales migrate far away

\section{Anthropogenic factors}

- Indigenous populations of native peoples in Arctic (Inuit, Sami, Yakut, etc.), none in Antarctic

- Antarctic whales found in many regions and so are less threatened than Arctic

- Arctic cetaceans more at risk

- Many populations settlements in and around Arctic, none in Antarctica 
- Arctic divided into territories owned by different countries; Antarctica has different sovereign claims but is shared resource with collaborative treaty

- Proximity to major population centers around Arctic leads to shipping lanes

- Antarctic stations focused mainly on research, but Arctic focus on research, military outposts, energy exploration

- Similar ozone holes, but closer factories and populations mean more acid rain and air/water pollution in Arctic

- Great effort to obtain oil and gas present in Arctic

- Potentially rich mineral deposits within rock of Antarctic continent and on/under Arctic Ocean seabed

- Ecotourism growing in both Arctic and Antarctic but easier in Arctic region

- Increasingly competitive claims to natural and other resources of Arctic

- High risk of vessel traffic (noise pollution, ship strikes, waste) for Arctic wildlife

- Greater threat to wildlife of Arctic

- Greater threat to wildlife of Arctic

- Much more energy exploration and extraction in Arctic vs. Antarctic

- Mining and mineral extraction possibly poses much more risk in Arctic

- Tourism can educate but also poses high environmental risk to Arctic

Table 2: Marine mammals found exclusively or commonly in the Arctic.

\begin{tabular}{|c|c|}
\hline Taxa & Arctic distribution \\
\hline \multicolumn{2}{|l|}{ Order Cetacea, Suborder Mysticeti } \\
\hline \multicolumn{2}{|l|}{ Family Balaenidae } \\
\hline Bowhead whale, Balaena mysticetus & Year-round Arctic \\
\hline \multicolumn{2}{|l|}{ Family Eschrichtiidae } \\
\hline Gray whale, Eschrichtius robustus & Frequent Arctic \\
\hline \multicolumn{2}{|l|}{ Family Balaenopteridae } \\
\hline Blue whale, Balaenoptera musculus & Occasional Arctic \\
\hline Fin whale, Balaenoptera physalus & Occasional Arctic \\
\hline $\begin{array}{l}\text { Humpback whale, Megaptera } \\
\text { novaeangliae }\end{array}$ & Occasional Arctic \\
\hline \multicolumn{2}{|l|}{ Order Cetacea, Suborder Odontoceti } \\
\hline \multicolumn{2}{|l|}{ Family Monodontidae } \\
\hline Beluga whale, Delphinapterus leucas & Year-round Arctic \\
\hline Narwhal, Monodon monoceros & Year-round Arctic \\
\hline \multicolumn{2}{|l|}{ Family Physeteridae } \\
\hline Sperm whale, Physeter macrocephalus & Occasional Arctic \\
\hline \multicolumn{2}{|l|}{ Family Delphinidae } \\
\hline Killer whale, Orcinus orca & Frequent Arctic \\
\hline \multicolumn{2}{|l|}{ Family Phocoenidae } \\
\hline Harbor porpoise, Phocoena phocoena & Frequent Arctic \\
\hline \multicolumn{2}{|l|}{ Order Carnivora } \\
\hline \multicolumn{2}{|l|}{ Family Ursidae } \\
\hline Polar bear, Ursus maritimus & Year-round Arctic \\
\hline \multicolumn{2}{|l|}{ Family Odobenidae } \\
\hline Walrus, Odobenus rosmarus & Year-round Arctic \\
\hline \multicolumn{2}{|l|}{ Family Phocidae } \\
\hline Bearded seal, Erignathus barbatus & Year-round Arctic \\
\hline Grey seal, Halichoerus grypus & Frequent Arctic \\
\hline Harbor seal, Phoca vitulina & Arctic and subarctic \\
\hline Harp seal, Pagophilus groenlandicus & Arctic and subarctic \\
\hline Hooded seal, Cystophora cristata & Arctic and subarctic \\
\hline Ribbon seal, Histriophoca fasciata & Arctic and subarctic \\
\hline
\end{tabular}

Ringed seal, Pusa hispida

Spotted seal, Phoca largha

Year-round Arctic

Arctic and subarctic

Note: other species of whales, dolphins, porpoises, and seals occasionally visit the Arctic but are rarely found there.

ra-Laptev complex north of western and central Russia, the Pacific Arctic stretching from Siberia to Alaska, and the Beaufort Sea north of Alaska and western Canada.

Altogether, the Arctic Ocean is unusual in that fully half of its area is made up of continental shelves, far more than is the case for the Southern, Indian, and North \& South Atlantic and Pacific Oceans. The Arctic Ocean contains many ridges, rises and shelves with plains, plateaus, and escarpments; it has many troughs, holes, and trenches (up to $5700 \mathrm{~m}$ deep), with extensive basins averaging 3,000$4,000 \mathrm{~m}$ in depth. It includes numerous active volcanoes, especially around its southern edges, and it has multiple large rivers that carry nutrients and other sediments into its basin [11-14]. There are several competing territorial claims, some settled and others disputed, for Arctic lands and waters and many energy prospects, especially for oil and gas fields. This is not surprising given that half of the world's petroleum deposits are estimated to lie within the Arctic, but there are also prospects for other sources including wind and tidal energy (Table 1).

\section{Arctic Marine Life}

Diverse invertebrates, fishes, and birds comprise a major portion of Arctic marine organisms, but mammals are among the most prominent and ecologically important animals of the Arctic, both in the sea (Table 2) and on land, including the Arctic hare (Lepus arcticus), Arctic fox (Vulpes lagopus), caribou (Rangifer tarandus), and musk ox (Ovibos moschatus), and lemmings of several species and genera. Of the marine mammals that spend considerable time in the Arctic, seven species are endemic (found only in this region): The bowhead whale, beluga whale, narwhal, walrus, bearded seal, ringed seal, and polar bear. Other marine mammals, notably four other seal species (harp, hooded, ribbon, and spotted seals), are non-endem- 
ic but found exclusively in the Arctic and subarctic regions, and additional baleen and toothed whales (gray and killer whales, respectively) are commonly found in Arctic waters (Table 2).

Many of the environmental dangers that threaten the Arctic $[1,4,7,11]$ also pose grave risk to the Antarctic [10] (Table 1). However, the Arctic is more vulnerable, particularly for marine life, for at least two reasons. First and foremost, a solid terrestrial continent lies at the heart of the Antarctic. In contrast, there is no land at the North Pole. Much of the Arctic above $70^{\circ} \mathrm{N}$ latitude is open water (apart from portions of Greenland, Ellesmere Island, and Franz Josef Land), with little land above $80^{\circ} \mathrm{N}$. Second, there is a greater human impact in the northern relative to southern polar region due to more settlement, transit, and economic activity in the Northern Hemisphere [11]. This is of course due to the larger current and historical human population of the north, which in turn is probably largely due to the far greater landmass of the Northern Hemisphere. This means that even though the center of the Antarctic is a frozen land, there is - because of the lesser amount of land in the Southern Hemisphere - a vast, circumpolar Southern Ocean where much marine life flourishes, and is at risk. Thus the Antarctic too faces many environmental threats, some of which threaten the Arctic. However, there are fewer marine mammals endemic to the southern polar region: just four species of phocid seals (Ross, Weddell, crabeater, and leopard seals) and no baleen or toothed whales found exclusively or most always around Antarctica (Table 2).

These and other geographic factors (Table 1) - such as the profusion of thousands of islands scattered across the Arctic, and the greater frequency of air and other pollution in the Northern Hemisphere due to the higher human population and economic activity from factories - render the Arctic especially vulnerable to environmental damage. Finally, although no part of the world is immune to grave environmental threats from pollution, habitat destruction, and climate change, the fact that the Arctic has historically been seen as an untapped pristine wilderness means that it has become a welcome target for tourism, exploration, and economic activity, while at the same time perhaps attracting less attention from conservation groups than tropical rain forests and reefs. Few people, including many scientists, understand how threatened the Arctic realm has become, and how it is in fact even more vulnerable to climate change and other transformative dangers than habitats at lower latitudes [1].

Couple this danger with the fact that polar regions are, because of their extreme seasonality, at times the most productive places on Earth (in terms of carbon capture and fixation per unit area), and one begins to see why the Arctic demands close scrutiny and protection [1-11].

The fragile simplicity of polar seas, often involving just two steps in a trophic chain [12-14], highlights their remarkable productivity but also their vulnerability to environmental damage [15-20]. In the Southern Ocean, much of the energy is captured by a superabundant pennate di- atom, Fragilariopsis kerguelensis, and this incredibly common phytoplankton becomes fodder for the superabundant zooplankton, the shrimp-like Euphausia superba, which in turn makes up nearly all of the diet of blue whales (Balaenoptera musculus) and other mysticetes. In the Arctic Ocean, there is a greater variety of phytoplankton (mostly diverse diatoms and dinoflagellates but also radiolarians, foraminiferans, etc.) which provide sustenance for diverse zooplankton, including many copepods, mysids, euphausiids, amphipods, and so on [12-14]. The fragility of polar seas cannot be minimized, especially as many aspects are currently at great risk - such as the abundant algae which grows on the lower (underwater) surface of sea ice [21-23], which is now melting at accelerated rates [15-20]. Studies are currently underway to determine the threats to Arctic wildlife posed by melting ice $[24,25]$. It might initially be assumed that the melting of ice and freeing up of more waterways might be a boon to Arctic marine mammals, particularly as it could lead to higher growth of plankton. However, the loss of plankton associated with sea ice might counterbalance the benefits of open seas. At the same time, this would lead to greater Arctic vessel traffic - especially of tanker and freighter ships through the fabled "Northwest Passage", which would cut East-West distances tremendously - would presumably decrease passage through the Panama and Suez Canals but amplify effects of environmental change in the Arctic. As Arctic albedo diminishes when highly reflective ice and snow melt and are replaced by darker, solar-absorbing ocean waters, the melting of the Arctic not only becomes a self-sustaining feedback loop but an ever-accelerating one [15-20].

This review summarizes current and projected threats, given current trends, to the trophic ecology (food, feeding method, foraging behavior, and digestive physiology) of marine mammal species that are found exclusively or commonly in the Arctic region (Table 2). These threats, many of which are anthropogenic in origin, have been categorized in Table 3. Some threats outlined in Table 3 pose a direct menace to marine mammals' trophic ecology by threatening the anatomy, physiology, ecology, or behavior of feeding; others pose an indirect threat by threatening, for example, prey species. Many relevant aspects of the biology of Arctic organisms, including their exceptionally long lifespans and dependence on thick blubber, have been documented in scientific literature yet overlooked in terms of risks posed by environmental threats to trophic ecology.

\section{Distinct Threats to Arctic Marine Life}

Many threats to Arctic wildlife have been well documented (Table 3); some of these risks apply to habitats all over the globe, including climate change, increased economic development and energy exploration, habitat degradation, loss of biodiversity, and many forms of pollution (air, water, soil, noise, etc.). For example, one highly publicized threat - the melting and loss of sea ice - poses direct and indirect threats to marine mammals of both Arctic and Antarctic polar regions, in that they depend directly on ice (for numerous ac- 
Citation: Werth AJ (2019) Evaluating Environmental Threats to the Trophic Ecology of Arctic Marine Mammals. J Mar Biol Aquaculture Res 2(1):17-24

Table 3: Major environmental threats to Arctic marine mammals summarized by category. This is not an exhaustive list but includes documented risks as well as those (especially arising from unique aspects of Arctic wildlife biology) that have to date received little research scrutiny.

\section{Causes}

\section{Consequences}

\section{Threats derived from Arctic Ocean geography \& topography}

A1: Relatively shallow depth of Arctic Ocean

A2: Relatively small area of Arctic Ocean

A3: Proximity to major human population centers and ports

A3a: Increased vessel traffic

A3al: Increased risk of ship strikes

A3all: Increased risk of vessel noise

A3allı: Increased disturbance from vessels $\&$ aircraft

A3alv: Increased pollution/waste from vessels $\&$ aircraft

A3b: Increased offshore oil \& gas exploration

A3bl: Increased risk of noise from seismic testing

A3bl: Increased risk of petroleum spills at wells

A3bl: Increased risk of petroleum spills from transport

A3bl: Risk from other energy capture (wind, tidal, etc.)

A3c: Increased commercial fishing in Arctic

A3d: Increased coastal development in Arctic

A3e: Increased tourism in Arctic

A3f: Increased deep sea mining in Arctic

A3fl: Increased risk of chemical contamination

A3fll: Weakened immune system

A3flll: Increased risk of disease

Easy for sediments to get into trophic web

Easy for sediments to get into trophic web

More people, more risk

More pollutant damage

Whales risk being struck

Noise risk to cetaceans

Air \& water pollution

Air \& water pollution

High risk of pollution

Noise risk to cetaceans

Oil damage to fauna

Oil damage to fauna

Threats at sea surface

Marine mammal bycatch, plus loss of prey

Coastal pollution, habitat loss

Pollution, energy use

Stirring up sediments etc.

Chemical pollution

Higher risk of disease

Morbidity \& mortality

\section{Threats derived from changing Arctic climate}

B1: Rise in sea surface temperature

Direct and indirect risk to marine mammals \& prey

B2: Sea level rise

B3: Melting of sea ice

B3a: Reduction in snow \& sea ice cover

B3a1: Direct habitat loss

Melting ice, habitat loss

Change in water salinity

Predator/prey habitat loss

Less ice for resting, molting, hunting, denning, reproduction, refuge, etc.

B3b: Thinner sea ice

B3c: Fewer polynyas and leads

B3d: More open water

Less algae, less habitat

Harder for marine mammals to find food

Less ice habitat for marine mammals \& prey

B3e: Reduction in ocean salinity

B3f: Alteration of deep ocean conveyor

B4: Melting of permafrost around Arctic Ocean boundaries

Changes to physiology \& prey abundance

Altered nutrient cycling and turnover

More runoff of nutrients

B4: Changes in prey species abundance

B5: Changes in prey species distribution

B5a: Alteration of predator-prey relationships

Less food for mammals

Harder to access food

Need to find other food

B6: Ocean acidification

B7: Longer seasons of open water

Changes to physiology of marine mammals \& prey

Habitat loss, less prey

\section{Threats related to biology of Arctic marine mammals}

C1: Heavy reliance on blubber for energy acquisition \& storage

C1a: Arctic whales \& seals have exceptionally thick blubber

C1b: Polar bears feed almost exclusively on blubber of prey

Many contaminants are stored in adipose tissue

High bioaccumulation risk, esp. over lifespan

Biomagnification in bears 
Citation: Werth AJ (2019) Evaluating Environmental Threats to the Trophic Ecology of Arctic Marine Mammals. J Mar Biol Aquaculture Res 2(1):17-24

\begin{tabular}{|c|c|}
\hline C2: Unusually long lifespan & Bowheads live $\gg 100 \mathrm{yrs}$ \\
\hline C2a: slow growth rate & Young animals grow slowly, putting them at high risk \\
\hline $\mathrm{C} 2 \mathrm{~b}$ : slow reproductive rate & Low fecundity and fragile reproductive biology \\
\hline C3: Extreme seasonality of habitat & Short summer feeding season and need to shelter during winter \\
\hline C4: Less migration than austral (southern) marine mammals & $\begin{array}{l}\text { Bowheads, narwhals, and belugas remain in Arctic, placing } \\
\text { them at risk }\end{array}$ \\
\hline C5: Thermoregulation is essential & $\begin{array}{l}\text { Bodies with less surface area have high volume to store } \\
\text { nutrients but also contaminants }\end{array}$ \\
\hline
\end{tabular}

tivities including resting, molting, reproduction and denning, and hunting for or refuge from predators) and also depend indirectly on ice for the plankton they eat or the fish or other animals that feed on plankton.

Ice is known to be a "food factory" for polar regions [21-23]. Research studies have shown that loss of Arctic sea ice has contributed to declines in the abundance as well as body size of the fatty copepods that whales and other Arctic animals depend on [8,14-18]. Reductions have also been documented in the benthic bivalves that walruses feed on, and the benthic crabs, urchins, and other macroinvertebrates, or the demersal fishes, that seals feed on.

The melting not only of floating land-fast (AKA shore-fast) ice but also glaciers, icebergs, and permafrost [14-21] is leading to other equally major and consequential outcomes for Arctic habitats and trophic webs. This melting is disrupting the thermohaline circulation of the global ocean. It is leading to release of carbon dioxide trapped in permafrost - one of the world's largest and most important carbon sinks. Such threats rightly attract much attention.

However, other environmental threats are both more specific to the Arctic and also less well known, in part because they involve unique aspects of Arctic biology. These distinct factors (Table 3 ) include special emphasis among Arctic animals (large and small) on thermoregulation, and thus a crucial effect of body size and surface-to-volume ratio so as to minimize heat loss in endotherms [26]. The unusually long lifespan of Arctic invertebrate and vertebrate animals (from clams and jellyfish to the bowhead whale and Greenland shark) render these polar species much more susceptible to environmental threats in many ways [27]. First, the slow growth rate puts them at increased risk. The slow reproduction rate generally leads to low fecundity and puts pressure on small broods of young organisms. The long lifespan also increases the likelihood of contaminating toxins or heavy metals accumulating and magnifying in the bodily tissues of Arctic fauna [28-34].

This bioaccumulation risk [35] is further magnified by the fact that Arctic marine mammals, more than those in the world's other oceans, depend extensively on thick blubber layers to survive, whether in the case of the whales and seals that need them as insulation to avoid radiative heat loss, or as predators like the polar bear which are known to feed almost exclusively on the blubber layers of seals and cetaceans when food is plentiful. Polar bears prefer blubber as a food source because it provides energy-dense calories [35]. Cetaceans and pinnipeds also use thick blubber for streamlining their bodies and to a great extent for storing nutrients for the long periods when food is unavailable [26].

This last consideration - the transient availability of food in the Arctic - is another key aspect of polar biology placing Arctic fauna at risk [36-39]. More so than other wildlife, Arctic marine mammals must feed during brief periods when food is available, then sustain their bodies for extended periods during the dark boreal winter. In the Antarctic, many marine mammals (especially toothed and baleen cetaceans) are not endemic to the region but migrate long distances to lower latitudes during the austral winter. Northern cetaceans including gray and bowhead whales do migrate, but bowheads - like narwhals and beluga whales - never leave the Arctic, placing them at greater risk from a plethora of environmental threats.

\section{Relevance of Arctic Trophic Ecoology}

Many biologists use the term "trophic ecology" to refer solely to exchange of nutrients within food webs [40-42]. In the broader sense used here - referring not only to diet but also to feeding method, foraging behavior, and digestive physiology [43-49] - Arctic marine mammals face other special risks.

For example, the ingestion of contaminants (heavy metals or chemicals such as chlorinated or brominated compounds) pose extreme dangers to Arctic marine mammals not only due to their thick blubber $[26,35]$ that accumulates over a long life time, but due to the shallow nature of the Arctic Ocean, with much upwelling of turnover and influx of chemicals from rivers and melting permafrost and glaciers $[1,24]$.

In terms of foraging for prey, the proliferation of chemicals in Arctic seas puts the ability of marine mammals to locate and capture food at risk [50]. The dimethyl sulfide (DMS) they are presumed to use as an olfactory cue can be diminished or overwhelmed by other chemicals, and the olfactory abilities of hunters can also be damaged. The special tissues that organisms use to capture and process prey [50], especially the oral baleen filter of mysticete whales, may be at risk from oil spills [51], plastic accumulation [51], and even changes in ocean acidification [5254]. Changes in the thermal properties of the Arctic Ocean may lead to more frequent storms and to different water circulation patterns, interrupting key ecological and behavioral patterns that whales and seals depend on to find the precious calories that sustain them through long Arctic 
winters [55].

\section{Conclusions}

Many Arctic marine mammals are already endangered (e.g., the bowhead whale, Balaena mysticetus) and can ill afford to face an onslaught of numerous other natural and human-induced threats that place not only their population size but indeed the species' very existence in doubt. Greater awareness of the distinct threats specifically targeting Arctic marine mammals is needed, as are more extensive oceanographic exploration of Arctic seas and detailed, focused research investigation of Arctic wildlife biology. Given the escalating nature of Arctic environmental dangers - with, for example, melting of polar sea ice rapidly accelerating in a vicious cycle due to greater solar absorption - there is little time to be lost in recognizing and combatting these severe environmental threats.

As future analysts and investigators evaluate both the likelihood and the potential magnitude of these and other diverse environmental threats to Arctic habitats, it is strongly recommended that they bear in mind not only general environmental risks but also those dangers specifically applicable to the Arctic due to its unique combination of geographic, climatological, and biological conditions and constraints. As apex predators of pelagic and littoral coastal habitats, marine mammals of the Arctic, including numerous endemic toothed and baleen whales, seals, and the polar bear, face grave risks related to food, feeding methods and mechanisms, foraging behaviors, and digestive physiology, all of which together make Arctic marine mammal trophic ecology a chief area of concern and future study.

\section{References}

1. CAFF: Conservation of Arctic Flora and Fauna (2017) Marine Mammals. In: RH Meehan, S Belikov, G Desportes, SH Ferguson, KM Kovacs, KL Laidre, GB Stenson, PO Thomas, F Ugarte, D Vongraven, State of the arctic marine biodiversity report. CAFF Secretariat, Akureyri, Iceland.

2. Moore SE, Kuletz KJ (2019) Marine birds and mammals as ecosystem sentinels in and near distributed biological observatory regions: An abbreviated review of published accounts and recommendations for integration to ocean observatories. Deep Sea Res Pt II 162: 211-217.

3. Davidson AD, Boyer AG, Kim H, et al. (2012) Drivers and hotspots of extinction risk in marine mammals. PNAS 109: 3395-3400.

4. Huntington HP (2009) A preliminary assessment of threats to arctic marine mammals and their conservation in the coming decades. Mar Policy 33: 77-82.

5. Clark A, Harris CM (2003) Polar marine ecosystems: major threats and future change. Envtl Conserv 30: 1-25.

6. Stirling I, Calvert W (1983) Environmental threats to marine mammals in the Canadian Arctic. Polar Rec 21: 433-449.

7. Nilsson A (1997) Arctic pollution issues: A state of the arctic environment report. Arctic Monitoring and Assessment Program (AMAP), Oslo, Norway.

8. Bossart GD (2010) Marine mammals as sentinel species for oceans and human health. Vet Pathol 48: 676-690.

9. Macdonald R (2005) Climate change, risks and contaminants: a perspective from studying the Arctic. Human and ecological risk assessment. 11: 1099-1104.

10. Bennett JR, Shaw JD, Terauds A, et al. (2015) Polar lessons learned: Long-term management based on shared threats in Arctic and Antarctic environments. Front Ecol \& Envt 13: 316324.

11. Laidre KL, Stern H, Kovacs KM, et al. (2015) Arctic marine mammal population status, sea ice habitat loss, and conservation recommendations for the $21^{\text {st }}$ century. Conserv Biol 29: 724-737.

12. Grebmeier JM, Frey KE, Cooper LW, et al. (2018) Trends in benthic macrofaunal populations, seasonal sea ice persistence, and bottom water temperatures in the Bering Strait region. Oceanogr 31: 136-151.

13. Hobson KA, Welch HE (1992). Determination of trophic relationships within a high Arctic marine food web using $\delta^{13} \mathrm{C}$ and $\delta^{15} \mathrm{~N}$ analysis. Mar Ecol Progr Ser 84: 9-18.

14. Hoekstra PF, Dehn LA, George JC, et al. (2002) Trophic ecology of bowhead whales (Balaena mysticetus) compared with that of other Arctic marine biota as interpreted from carbon-, nitrogen-, and sulfur-isotope signatures. Can J Zool 80: 223-231.

15. Learmonth JA, MacLeod CD, Vasquez MBS, et al. (2006) Potential effects of climate change on marine mammals. Oceanogr Mar Biol Ann Rev 44: 431-464.

16. Moore SE, Huntington HP (2008) Arctic marine mammals and climate change: Impacts and resilience. Ecol Appl 18: 157-165.

17. Simmonds MP, Isaac SJ (2007) The impacts of climate change on marine mammals: Early signs of significant problems. Oryx 41: 19-26.

18. Burek KA, Gulland FMD, O'Hara T (2008) Effects of climate change on Arctic marine mammal health. Ecol Appl 18: 126-134.

19. Wang M, Overland JE (2012) A sea ice-free summer Arctic within 30 years: An update from CMIP5 models. Geophys Res Lett 39.

20. Ragen TJ, Huntington HP, Hovelsrud GK (2008) Conservation of Arctic marine mammals faced with climate change. Ecol Appl 18: 166-174.

21. Gradinger R (2009) Sea ice algae: Major contributors to primary production and algal biomass in the Chukchi and Beaufort Seas during May/June 2002. Deep Sea Research Pt II 56: 1201-1212.

22. Mundy JC, Barber DG, Michel C (2005) Variability of snow and ice thermal, physical, and optical properties pertinent to sea ice algae biomass during spring. J Mar Syst 58: 107-120.

23. Rysgaard S, Kuhl M, Glud RN, et al. (2001) Biomass, production, and horizontal patchiness of sea ice algae in a high-Arctic fjord. Mar Ecol Progr Ser 223: 15-26.

24. Stirling I (1980) The biological importance of polynyas in the Canadian Arctic. Arctic 33: 303-315.

25. Eicken H (2013) Arctic sea ice needs better forecasts. Nature 497: 431-433.

26. Ford TJ, Werth AJ, George JC (2013) An intraoral thermoregulatory organ in the bowhead whale (Balaena mysticetus), the corpus cavernosum maxillaris. Anat Rec 296: 701-708.

27. George JC, Stimmelmayr R, Suydam R, et al. (2016) Severe bone loss as part of the life history strategy of bowhead whales. PLoS One 11: e0156753. 
28. Muir DCG, Wagemann R, Hargrave BT, et al. (1992) Arctic marine ecosystem contamination. Sci Total Env 122: 75-134.

29. Dietz R, Bossi R, Riget FF, et al. (2008) Increasing perfluoroalkyl contaminants in East Greenland polar bears (Ursus maritimus): A new toxic threat to the Arctic bears. Environ Sci Technol 42: 2701-2707.

30. Scheuhammer AM, Meyer Mw, Sandheinrich MB, et al. (2007) Effects of environmental methylmercury on the health of wild birds, mammals, and fish. Ambio 36: 12-19.

31. Macdonald RW, Bewer JM (1996) Contaminants in the arctic marine environment: priorities for protection. ICES J of Mar Sci 53: 537-563.

32. Brunstrom B, Halldin K (2000) Ecotoxicological risk assessment of environmental pollutants in the Arctic. Toxicol Lett 112: 111118.

33. Tanabe $S$ (2002) Contamination and toxic effects of persistent endocrine disrupters in marine mammals and birds. Mar Poll Bull 45: 69-77.

34. Tomy GT, Budakowski W, Halldorson T, et al. (2004) Fluorinated organic compounds in an Eastern Arctic marine food web. Environ Sci Technol 38: 6475-6481.

35. Atwell L, Hobson KA, Welch HE (1998) Biomagnification and bioaccumulation of mercury in an Arctic marine food web: insights from stable nitrogen isotope analysis. Can J Fish Aq Sci 55: 11141121.

36. Taylor BL, Martinez M, Gerrodette T, et al. (2006) Lessons from monitoring trends in abundance of marine mammals. Mar Mamm Sci 23: 157-175.

37. Huntington HP, Daniel R, Hartsig A, et al. (2015) Vessels, risks, and rules: Planning for safe shipping in the Bering Strait. Mar Pol 51: 119-127.

38. Guldberg OH, Bruno JF (2010) The impact of climate change on the world's marine ecosystems. Sci 328: 1523-1528.

39. Halpern BS, Selkoe KA, Micheli F, et al. (2007) Evaluating and ranking the vulnerability of global marine ecosystems to anthropogenic threats. Conserv Biol 21: 1301-1315.

40. Christoffersen ML, Araujo ME, Branco JO (2011) An overview of studies on trophic ecology in the marine environment: achievements and perspectives. Neotrop Biol Conserv 6: 143-155.

41. Palkovacs EP, Hendry AP (2010) Eco-evolutionary dynamics: intertwining ecological and evolutionary processes in contempo- rary time. F1000 Biol 2: 1.

42. Budge SM, Iverson SJ, Koopman HN (2006) Studying trophic ecology in marine ecosystems using fatty acids: A primer on analysis and interpretation. Mar Mamm Sci 22: 759-801.

43. Heithaus MR, Aaron AF, Wirsing AJ, et al. (2008) Predicting ecological consequences of marine top predator declines. Trends in Ecol \& Evol 23: 202-210.

44. Vascocellosa M, Mackinson S, Sloma K, et al. (2007) The stability of trophic mass-balance models of marine ecosystems: a comparative analysis. Ecol Model 100: 125-134.

45. Terborgh J, Estes JA (2010) Trophic cascades: Predators, prey, and the changing dynamics of nature. Island Press, Washington, DC.

46. Ripple WJ, Estes JA, Beschta RL, et al. (2014) Status and ecological effects of the world's largest carnivores. Sci 343: 1241484.

47. MacKinner MA, Peacock E, Letcher RJ (2009) Sea ice-associated diet change increases the levels of chlorinated and brominated contaminants in polar bears. Environ Sci Technol 43: 4334-4339.

48. Schmitz OJ, Krivan V, Ovadia O (2004) Trophic cascades: the primacy of trait-mediated indirect interactions. Ecol Lett 7: 153163.

49. Williams TM, Estes JA, Doak DF, et al. (2004) Killer appetites: Assessing the role of predators in ecological communities. Ecol 85: 3373-3384.

50. Werth AJ (2012) Hydrodynamic and sensory factors governing response of copepods to simulated predation by baleen whales. Int J Ecol.

51. Werth AJ, Blakeney SM, Cothren Al (2019) Oil adsorption does not structurally or functionally alter whale baleen. Roy Soc Open Sci 6.

52. Werth AJ, Whaley HR (2019) Ocean acidification's potential effects on keratin protein in cetacean baleen and other integumentary tissue. Ann Ecol Envtl Sci 3: 21-28.

53. Caldeira K, Wickett ME (2003) Anthropogenic carbon and ocean pH. Nature 425: 365.

54. Hall-Spencer JM, Rodolfo-Metalpa R, Martin S, et al. (2008) Volcanic carbon dioxide vents show ecosystem effects of ocean acidification. Nature 454: 96-99.

55. Moore SE (2016) Is it 'boom times' for baleen whales in the Pacific Arctic region? Biol Lett 12. 